\title{
Green Corrosion Inhibitors to Head Off the Corrosion Rate of ST 37 Steels
}

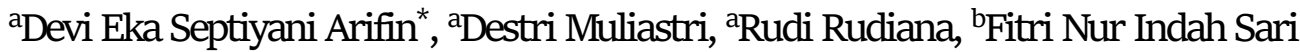 \\ aDepartment of Mechanical Engineering, Politeknik Negeri Bandung, Bandung 40559, Indonesia \\ bMaterials Science and Engineering, National Cheng-Kung University, Tainan 701, Taiwan
}

Received 29 September 2020; accepted 25January 2021

\begin{abstract}
The corrosions process is a natural process and cannot be hindered, but it can be protected by adding a green inhibitor. Green corrosion inhibitors are a new alternative solution for corrosion protection because they are low-cost, biodegradable, and eco-friendly inhibitors. This research was used papaya leaves dan guava leaves extract as organic inhibitor solution by Maceration Method. The concentration of these green inhibitors is o $\mathrm{mL}, 1 \mathrm{~mL}, 2.5 \mathrm{~mL}, 3$ $\mathrm{mL}$, and $3.5 \mathrm{~mL}$. The type of testing method used in this research is FTIR, PDP, and weight loss. The results show that there is Tanin function groups in papaya leaves and guava leaves extract. The potentiodynamic polarization shows the value of corrosion rate without inhibitor is $0,418 \mathrm{~mm} /$ year. In contrast, the corrosion rate was decreased with improving the green inhibitor as many $3.5 \mathrm{~mL}$. The corrosion rate was decreased until o,00055 mm/year, and the value of efficiency is $99,868 \%$.
\end{abstract}

\section{KEYWORDS}

Green inhibitor

Papaya leaves

Guava leaves

Corrosion rate

\section{INTRODUCTION}

The phenomenon of corrosion is a persistent problem. Especially in theindustrial sector. Disasters and disadvantages caused by corrosion. The disadvantages are not only limited to material losses but also safety. Corrosion cannot be prevented and occurs naturally. However, it can be controlled by several methods such as the process of material selection, coating material, changes in metal potential, and changes in environmental conditions (Rani \& Basu, 2012).

Corrosion is the reaction with its environment, which causes a metal degradation by a chemical attack (Abelson, 1988). These environments are water, acid solutions, alkaline solutions, air, brine, and other corrosive media. The results of corrosion reaction cause material or metals will be changes (either physical or chemical), which means that the ability of the material will decrease (Gobara et al., 2020). The process of corrosion involves two chemical reactions. They are reduction and oxidation processes (Sanjaya et al., 2018). When the specimen of pure metal was immersed in the electrolyte solutions that contain specimen ions, the metal ions will tend to dissolves into it. The metal surface will start the redeposition process to retain the properties of 
these metals. The transfer of metal ions to a liquid medium is called the oxidation process (loss of electrons), and its redeposition causes reduction (Sari et al., 2013).

Almost all metals and alloys are susceptible to have corrosion degradation (Sanni et al., 2019). One of them is ST 37 Steel. ST 37 steel is plain carbon steel (code $=1045$ ) with a maximum Mn content is 1,00 \% based on the AISI standard. Based on the carbon content, ST 37 steel is a type of medium carbon steel. It has a hardness number $\pm 51.66 \mathrm{HRA}$, tensile strength is 650 $800 \mathrm{~N} / \mathrm{mm}^{2}$, and an average corrosion rate is $1.819 \mathrm{~mm} /$ year (Susila et al., 2017)(Kirono \& Amri, 2013). The composition of ST 37 steel is explained in table 1 below.

Table 1. The composition of ST 37 steels

\begin{tabular}{cc} 
Name of Compound & Composition (\%) \\
\hline Carbon (C) & 0,24 \\
\hline Mangan (Mn) & 0,90 \\
\hline Phosphorus (P) & 0,035 \\
\hline Sulfur (S) & 0,04 \\
\hline Silicon (Si) & $0,15-0,4$ \\
\hline Chromium (Cr) & - \\
\hline Nickel (Ni) & - \\
\hline Molybdenum (Mo) & - \\
\hline Nitrogen(N) & - \\
\hline Copper (Cu) & 0,2
\end{tabular}

The prevention of corrosion is by using an inhibitor. Corrosion inhibitors can prevent or minimize corrosion when adding it even in a small concentration to an electrolyte solution by forming a monomolecular layer on the surface to prevent the direct contact between metal and electrolyte solution (corrosion medium) (Popoola, 2019). However, there are some problems in the selection of suitable inhibitor substances. They include the toxic effect on the environment, the cost and amount of the inhibitor are also required (Sanni et al., 2019).

Currently, a green inhibitor is one of the alternative solutions to prevent the corrosion rate because of its cheap, biodegradable, and eco-friendly inhibitor. Green inhibitors are obtained from plant extracts such as leaves, fruit, and fruit peels (Goyal et al., 2018). The requirement of a green inhibitor is the element content of N, O, P, S. The inhibitor can protect the metal by forming a hydrophobic layer on the metal surface. The nitrogen group in the inhibitor compound has a free electron pair which causes the inhibitor to be negatively charged so that the inhibitor will form a layer on the metal surface (Sari et al., 2013).

Several researchers have succeeded in developing these natural inhibitors to prevent corrosion of metals in acid solutions and alkaline. Sri Handani et al. had been researched the coating of papaya leaves extract on the carbon steel of schedule 40 grade B ERW, which was immersed in seawater and shows that the corrosion rate decreased significantly at all variations of immersion time (Handani \& Elta, 2012). Rondang Tambun et al. showed that the iron plate corrosion rate decreased with the addition of guava leaves as inhibitor organics in the $2 \mathrm{~N} \mathrm{HCl}$ solutions. The addition of inhibitor is 9 grams, and the immersion process is 12 days (Tambun et al., 2015).

Another researcher is Arri Prasetyo from The University of Indonesia, carried out adding rosella flower tea as an organic inhibitor to low carbon steel using the polarization method. From 
these studies, rosella flower tea inhibitors can inhibit the corrosion rate with an efficiency of 57.32 $-59.31 \%$ by adding a concentration of $2-8 \mathrm{~mL}$ of rosella flower tea in $3.5 \% \mathrm{NaCl}$ solutions. Indah Lestari et al. had been done research using karamunting leaves extract as an organic inhibitor. This study showed that the organic inhibitor caused the corrosion rate of $\mathrm{Al}$ decreased with inhibitory power is $1.23 \%$ (Lestari et al., 2018).

In this research, papaya leaves and guava leaves will be used as green inhibitors with the maceration method. The green inhibitor is added to $3.5 \% \mathrm{NaCl}$ solutions to know the corrosion rate and efficiency of the ST 37 steel.

\section{METHODS}

\section{Materials}

ST 37 steel is used in this experiment which is ST 37 steel is plain carbon steels.

\section{The Extraction of Green Inhibitor}

Papaya leaves and guava leaves were cleaned and dried at room temperature for seven days to remove water from the leaves. Papaya and guava leaves were mixed by blender with a 1:1 ratio. The extraction process was used the maceration method. The maceration method is the soaking process of papaya and guava leaves powder in ethanol $96 \%$ for seven days. Then, the solutions were filtered using filter paper and let the ethanol evaporate by heating and string on the hot plate to get papaya and guava leaves potent extract. Papaya and guava leave strong extract was tested by Fourier Transform Infrared Spectroscopy (FTIR).

\section{Corrosion Medium Solutions}

Corrosion medium solutions was used $\mathrm{NaCl} 3.5 \%$ solutions. 3.5 grams of $\mathrm{NaCl}$ was dissolved in 96.5 $\mathrm{mL}$ of demineralized water.

\section{Sample preparation for PDP test}

The size of the specimen for the Potensiodynamic Polarization (PDP) test is $2 \times 2 \mathrm{~cm}$. Then, the specimen was cleaned with sandpaper to remove dust and corrosion.

\section{Sample preparation for Weight Loss test}

The size of the specimen for the weight loss test is $2.5 \times 5.5 \mathrm{~cm}$. first, Then, the specimen was cleaned with sandpaper to remove dust and corrosion or coating corrosion on the face of steels. Then, the specimen was cleaned with 70\% of alcohol and weighing specimen-the calculation of weight loss test based on ASTM G31-72 standard. 


$$
\text { Corrosion Rate }=\frac{K \times W}{A \times T \times \rho}
$$

Where

$W$ : Weight Loss (gram)

$K$ : Constanta of corrosion rate

$\rho$ : Density $\left(\mathrm{gr} / \mathrm{cm}^{3}\right)$

$A$ : Wide Area $\left(\mathrm{vm}^{2}\right)$

$T$ : Time (hours)

\section{RESULTS AND DISCUSSION}

\section{The Characteristics of Green Inhibitors}

The extraction of papaya leaves and guava leaves using the maceration method was produced oil, which contains compounds that can protect against the corrosion rate. The color of the oil is dark green and has a low viscosity. Figure 1 shows the results of the extraction of papaya leaves and guava leaves.

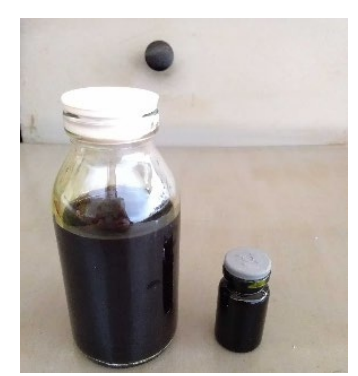

Figure 1. papaya leaves and guava leaves extract

Papaya leaves and guava leaves extract was tested by Fourier Transfer Infrared (FTIR). FTIR test was carried out to determine the functional groups of the green inhibitors, especially the functional groups of tannin. The functional groups of tannin, which are found in the FTIR test was shown in table 2.

\begin{tabular}{cccc}
$\begin{array}{c}\text { Frequency of green inhibitor } \\
\left(\mathrm{cm}^{-1}\right)\end{array}$ & $\begin{array}{c}\text { Table 2. Functional groups of tannin } \\
\text { Correlation of } \\
\text { frequency Range } \\
\left(\mathrm{cm}^{-1}\right)\end{array}$ & Chain & Types and Groups \\
\hline 3296.44 & $3230-3400$ & $\mathrm{O}-\mathrm{H}$ & $\begin{array}{c}\text { R-OH, Ar-OH } \\
\text { polymeric }\end{array}$ \\
\hline 2975.31 & $2850-2970$ & C-H & \\
\hline 1444.85 & $1340-1470$ & C-H & \\
\hline 1405.58 & $1340-1470$ & C-H & \\
\hline 1016.72 & $1000-1300$ & C-O & $\begin{array}{c}\text { Carbonyl compound } \\
\text { (Anhydride acyclic) }\end{array}$ \\
\hline 1084.45 & $1000-1300$ & C-O & $\begin{array}{c}\text { Carbonyl compound } \\
\text { (Anhydride acyclic) }\end{array}$ \\
\hline 878.22 & $675-995$ & C-H &
\end{tabular}


The FTIR results of green inhibitor showed that the value of wavelength and the value of intensity indicate the functional group of green inhibitor extract. The FTIR results of functional groups in figure 2 are compared with the FTIR reference for papaya leaves, and guava leaves FTIR, whether they form a tannin structure or not. Figure 2 shows the presence of tannin functional groups according to table 2 .

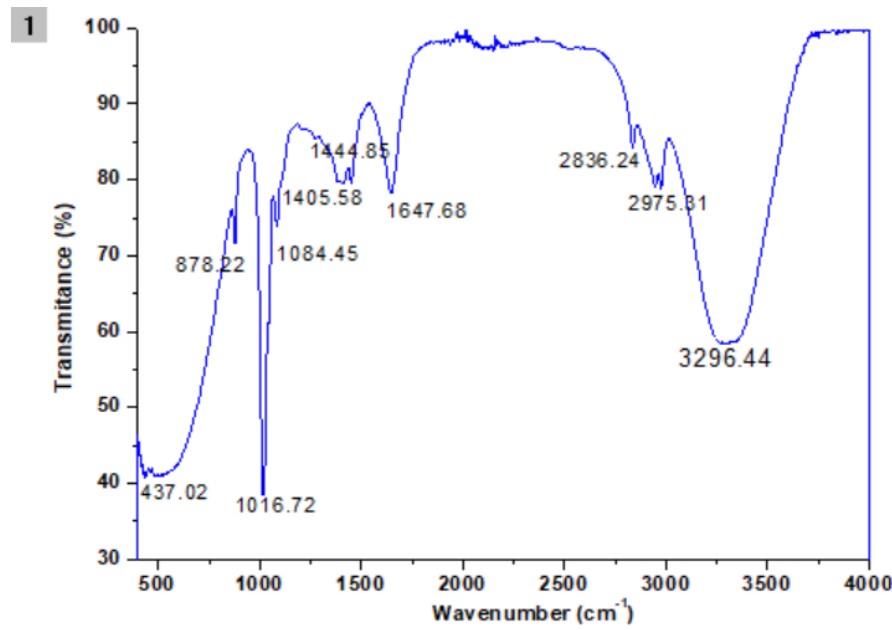

Figure 2. graphics of FTIR papaya leaves and guava leaves extract

\section{Corrosion Rate of ST 37 Steels}

The corrosion rate of the ST 37 steel plate can be conducted by PDP test. In addition, inhibition efficiency was determined in the PDP test also. The result of this test is a Tafel polarization curve. Tafel curve can be seen in figure 3, where the potential (E) curve is proportional to log i. PDP test was used Tafel curve fit by drawing linear lines on both sides of the inner curve so that the Icorr value is generated, the $b_{a}$ (slope of anodic Tafel reaction) and $b_{c}$ (slope of cathodic Tafel reaction) values. The density of ST 37 steel is $7.5 \mathrm{~g} / \mathrm{cm}_{3}$, and the equivalent weight (EW) is $27.9235 \mathrm{~g} / \mathrm{mol}$. Based on these parameters, the corrosion rate (CR) was obtained. The results showed in Table 3.

\begin{tabular}{ccccccc}
$\begin{array}{c}\text { Konsentrasi } \\
(\mathrm{mL})\end{array}$ & $\begin{array}{c}\text { Table 3. corrosion rate of green inhibitor based on PDP test } \\
\mathrm{b}_{\mathbf{a}}\end{array}$ & $\mathrm{b}_{\mathrm{c}}(\mathrm{mV} / \mathrm{dec})$ & Ecorr (V) & Icorr (A) & CR (mm/year) & \%IE \\
\hline 0 & 165,72 & 142,44 & $-0,54511$ & $\begin{array}{c}3,4339 \\
\times 10^{-5}\end{array}$ & 0,4178 & \\
\hline 1 & 79,734 & 367,76 & $-0,54837$ & $\begin{array}{c}3,4319 \\
\times 10^{-6}\end{array}$ & 0,041757 & 90,00551 \\
\hline 2,5 & 115,61 & 69,616 & $-0,45806$ & $\begin{array}{c}2,4876 \\
\times 10^{-6}\end{array}$ & 0,030266 & 92,75586 \\
\hline 3 & 156,43 & 62,683 & $-0,3773$ & $\begin{array}{c}3,5302 \\
\times 10^{-7}\end{array}$ & 0,0042952 & 98,97195 \\
\hline 3,5 & 380,83 & 136,87 & $-0,27895$ & $\begin{array}{c}4,5277 \\
\times 10^{-8}\end{array}$ & 0,00055089 & 99,86815
\end{tabular}


The highest corrosion rate value shown in the concentration without green inhibitor is 0.041757 . The lowest corrosion rate is 0,000551 at a $3.5 \mathrm{~mL}$ concentration of green inhibitor with the highest inhibition efficiency of 99.868\%. These results are appropriate with figure 3. Figure 3 showed that Tafel extrapolation curves before and after the addition of green inhibitor, seen that the current corrosion was decreased. Corrosion current and corrosion rate have a linear relationship.

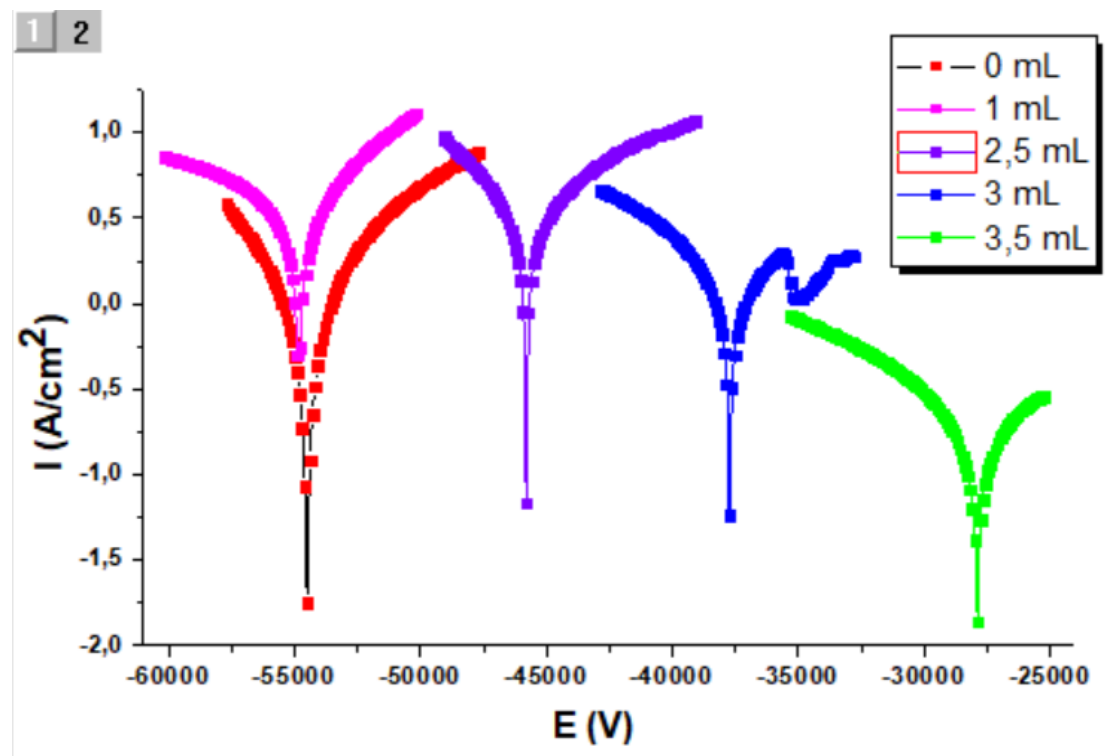

Figure 3. the results of PDP test

In the PDP test process, the sample was inserted in electrolyte solution then the electron will moving from the anode to the cathode. The more electrons moving from the anode to the cathode, the current corrosion will be higher. Figure 3 showed that the $3,5 \mathrm{~mL}$ concentration has lower current corrosion so that the corrosion rate will be lower.

Another method to measure corrosion rate is the weight loss test. The test is carried out by weighing the initial weight of ST 37 steel plate, then immersion into a 3.5\% NaCl solution with the addition of variations in the concentration of inhibitor o $\mathrm{mL}, 1 \mathrm{~mL}, 2.5 \mathrm{~mL}, 3 \mathrm{~mL}$, dan $3.5 \mathrm{~mL}$, which were immersed for seven days. The results of the weight loss test can be seen in figure 4 below.

Figure 4 showed that the corrosion rate decreased when ST 37 steel plate was immersed with a green inhibitor. Because of the addition of green inhibitor can against the metals by forming a hydrophobic layer on the metal surface. The nitrogen groups in theinhibitor compound have free electron pairs that cause the inhibitor to have negatively charged then the inhibitor will form a layer on the metal surface. 


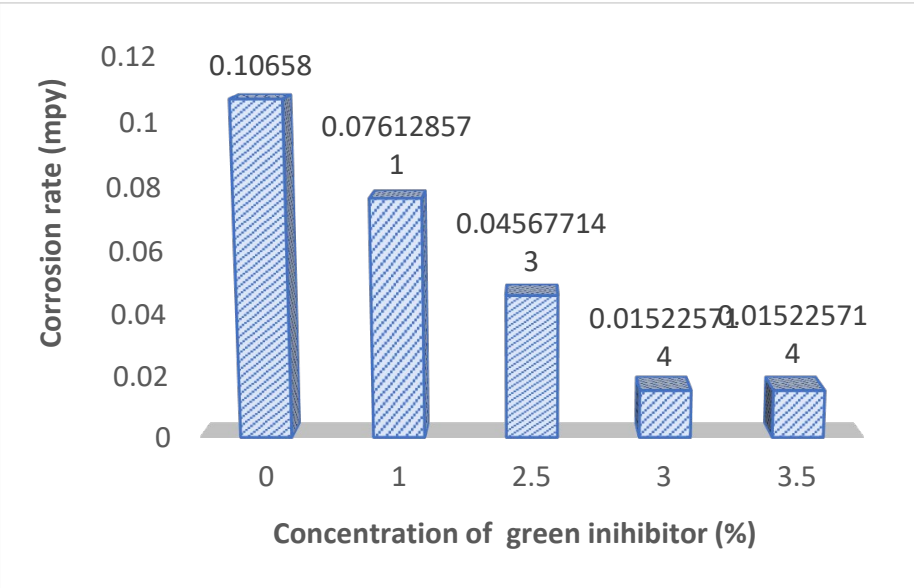

Figure 4. Graphics of the correlation between concentration of green inhibitor and corrosion rate

\section{CONCLUSION}

The results show that there are Tanin, functional groups, in papaya leaves and guava leaves extract based on the FTIR test. The potentiodynamic polarization shows the value of corrosion rate without inhibitor is $0.418 \mathrm{~mm} /$ year. At the same time, the corrosion rate was decreased with improving the green inhibitor as many $3.5 \mathrm{~mL}$. The corrosion rate was decreased until 0,00055 $\mathrm{mm} /$ year, and the value of efficiency is $99.868 \%$. The same results showed in the weight loss test. The lowest corrosion rate is $0.0152 \mathrm{~mm} /$ year at a $3.5 \mathrm{~mL}$ concentration of green inhibitor. When the corrosion rate is low, it will be effective against the corrosion process.

\section{REFERENCES}

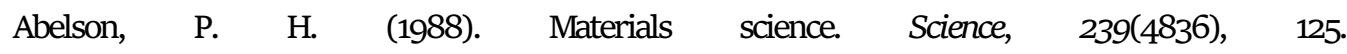
https://doi.org/10.1126/science.239.4836.125.

Gobara, M. Baraka, A., Akid, R., \& Zorainy, M. (2020). Corrosion protection mechanism of Ce4+/organic inhibitor for AA2O24 in 3.5\% NaCl. RSC Advances, 10(4), 2227-2240. https://doi.org/10.1039/c9rao9552g.

Goyal, M., Kumar, S., Bahadur, I., Verma, C., \& Ebenso, E. E. (2018). Organic corrosion inhibitors for industrial cleaning of ferrous and non-ferrous metals in acidic solutions: A review. Journal of Molecular Liquids, 256(February), 565-573. https://doi.org/10.1016/j.molliq.2018.02.045.

Handani, S., \& Elta, M. S. (2012). Pengaruh Inhibitor Ekstrak Daun Pepaya Terhadap Korosi Baja Karbon Schedule 40 Grade B Erw Dalam Medium Air Laut Dan Air Tawar. Jurnal Riset Kimia, 5(2), 175. https://doi.org/10.25077/jrk.v5i2.219.

Kirono, S., \& Amri, A. (2013). Pengaruh Tempering Pada Baja ST 37 Yang Mengalami Karburasi Dengan Bahan Padat Terhadap Sifat Mekanis dan Struktur Mikro. Jurusan Mesin, Universitas Muhammadiyah Jakarta, C, 1-10.

Lestari, I., Rodyatunnisa, Sakinah, N., \& Mardiah. (2018). Studi Laju Korosi Logam Aluminium Dengan Penambahan Inhibitor Dari Ekstrak Daun Karamunting (Rhodomyrtus Tomentosa ). 7(1), 26-31.

Popoola, L. T. (2019). Organic green corrosion inhibitors (OGCIs): A critical review. Corrosion Reviews, 37(2), 71-102. https://doi.org/10.1515/corrrev-2018-0058. 
Rani, B. E. A., \& Basu, B. B. J. (2012). Green inhibitors for corrosion protection of metals and alloys: An overview. International Journal of Corrosion, 2012(i). https://doi.org/10.1155/2012/380217.

Sanjaya, A. S., Mardiah, M. Novianti, H. L., \& Fadilah, O. A. (2018). Penurunan Laju Korosi Logam Aluminium Menggunakan Inhibitor Alami. Jurnal Chemurgy, 2(1), 30. https://doi.org/10.30872/cmg.v2i1.2612.

Sanni, O., Sunday Isaac Fayomi, O., \& Patricia Idowu Popoola, A. (2019). Eco-friendly Inhibitors for Corrosion Protection of Stainless steel: An Overview. Journal of Physics: Conference Series, 1378(4). https://doi.org/10.1088/1742-6596/1378/4/042047.

Sari, D., Handani, S., \& Yetri, Y. (2013). Pengendalian Laju Korosi Baja St-37 Dalam Medium Asam Klorida Dan Natrium Klorida Menggunakan Inhibitor Ekstrak Daun Teh (Camelia Sinensis). Jurnal Fisika Unand, 2(3), 204-211.

Susila, Y. A., Prayitno, D., Mesin, T., \& Trisakti, U. (2017). KARAKTERISASI BAJA SMO 254 \& BAJA ST 37 YANG DI-ALUMINIZING. 265-271.

Tambun, R., Limbong, H. P., Nababan, P., \& Sitorus, N. (2015). Kemampuan Daun Jambu Biji sebagai Inhibitor Korosi Besi pada Medium Asam Klorida. In Jurnal Kimia dan Kemasan (Vol. 37, Issue 2, p. 73). https://doi.org/10.24817/jkk.v37i2.1815. 